\title{
1 Characteristics of, and uncertainties about, illegal jaguar trade in Belize and Guatemala
}

\section{Abstract}

3 Recent reports of jaguar trade have emerged throughout Latin America, but, although trade is now

4 considered a high-priority threat to jaguars, its characteristics remain largely unknown. We aimed to 5 gain a deeper understanding of the status of jaguar trade in Mesoamerica, focusing on Belize and 6 Guatemala. We used key-informant interviews to explore the pathways behind the jaguar trade 7 chain, identify the characteristics and motivations of the actors involved, and investigate the drivers 8 and enabling factors behind jaguar trade. We distinguished between concrete evidence and strong 9 beliefs or assumptions, thereby highlighting key areas for conservation action and of uncertainty.

10 Our results suggest that jaguar trade is present in Belize and Guatemala, although current examples 11 suggest it is a domestically-focused and opportunistic activity, rather than an organized international 12 trade. Key drivers included human-wildlife conflict, opportunistic hunting, Chinese demand, drug 13 trafficking, migration, and tourism. The areas of higher uncertainty are the role of external actors 14 and drivers, and of commercial motivations. The main legal and institutional challenges to address 15 this threat include the lack of resources, ineffectiveness of law enforcement, animosities between communities and the government, corruption, outdated legal systems, missing evidence, the lack of mandate of wildlife authorities and safety concerns. Key priorities for conservation interventions and research to prevent jaguar trade from escalating in these countries are to invest in local communities living in proximity to jaguars, while also investigating the role of external actors in jaguar trade, which remained largely uncertain throughout this study.

\section{Key words}

22 Large carnivore conservation; Human-wildlife conflict; Hunting; Uncertainty; Drivers; Enabling 


\section{Introduction}

Illegal Wildlife Trade (IWT) is one of the most pressing global conservation issues, affecting thousands of species worldwide, with repercussions for biodiversity, the environment and human health and wellbeing (T Sas-Rolfes et al., 2019). IWT has become one of the most profitable illicit sectors, worth billions of dollars per year (May and Clough, 2017). It is often associated with criminal networks, with important implications for national security (Nellemann et al., 2014; Zimmerman, 2003). Despite increased investments to strengthen enforcement and curb the demand for wildlife products, IWT continues to escalate and expand into new markets (UNODC, 2016), enabled by factors like poverty, corruption, and a lack of institutional capacity, legislation, enforcement and community engagement (Harrison et al., 2015; Nellemann et al., 2014). To date, most efforts to understand and address IWT have focused on Africa and Asia, where megafauna such as elephants and tigers are declining due to demand from Asian markets (Sanderson et al., 2010; Wittemyer et al., 2014). Less attention has been given to the issue in Latin America, which represents less than $10 \%$ of peer-reviewed literature on illegal wildlife harvesting published between 1990-2014 (Kahler and Gore, 2017), leaving important gaps in our understanding of IWT in the region (Reuter et al., 2018a).

Among these gaps is the recent trade in jaguars (Panthera onca) for domestic and international markets. Jaguars have had a long history of exploitation and trade by numerous indigenous civilizations in Central and South America, being part of their cultural symbolism since pre-colonial times (Laffoon et al., 2014; Saunders, 1998). Beyond their traditional value, jaguars were legally hunted through most of the $20^{\text {th }}$ century for the international fur industry, until they were listed on Appendix I of the Convention on International Trade in Endangered Species of Wild Fauna and Flora (CITES) in 1975, thereby halting legal commercial international trade (CITES, 2017). Even though killing, possessing or commercializing jaguars and their body parts is prohibited in most of the jaguar range (Quigley et al., 2017), it still occurs, mainly in the context of retaliation to livestock depredation by jaguars (which we refer to as human-jaguar conflict in the remaining of the text). While human-jaguar conflict has become a fairly well documented threat to jaguar populations (Inskip and Zimmermann, 2009), the trade in jaguar body parts has received less attention. Most existing reports of jaguar use and trade are secondary findings in studies of human-jaguar conflict or jaguar distributions (e.g. Briones-Salas et al., 2012; Figel et al., 2016).

Recently, however, jaguar trade has begun to draw the interest of conservation researchers, practitioners and governments following the emergence of evidence linking the trade with Asian demand. In Bolivia, authorities intercepted hundreds of jaguar teeth destined for China between 2014 and 2017 (Nunez and Aliaga-Rossel, 2017). Soon afterwards came reports of Chinese demand for jaguar bone-paste medicine in Suriname (Lemieux and Bruschi, 2019; Verheij, 2019). These highprofile cases revealed widespread evidence of trade of jaguar body parts (Morcatty et al., 2020). In Mesoamerica, Harmsen \& Urbina, (2017) found concrete evidence of jaguar body part ownership in the main cities of Belize. Kelly, (2018a) identified links between possession of jaguar body parts, wealth and masculine identity in urban areas of Costa Rica, and Reuter et al, (2018b) hypothesized that human-jaguar conflict and Chinese presence may be acting as drivers of jaguar trade throughout Mesoamerica. However, these authors highlighted information gaps concerning the drivers, enabling factors and characteristics of jaguar trade in Mesoamerica.

We therefore aimed to gain a deeper understanding of the status of jaguar trade in Mesoamerica. Focusing on Belize and Guatemala as case studies, we analysed recent examples of jaguar trade from key informant interviews to delineate the pathways behind the jaguar trade chain, develop typologies of trade actors, and explore their motivations. We also investigated the broader drivers and enabling factors of jaguar trade, to pinpoint key opportunities for conservation interventions in these countries. Throughout this exploratory analysis, we placed a particular emphasis on 
distinguishing between concrete evidence and strong beliefs or assumptions, thereby highlighting critical points of uncertainty about the jaguar trade.

\section{Methods}

\subsection{Study sites}

We selected Belize and Guatemala due to anecdotal and official reports of jaguar trade. In addition, they contain critical fragments of Mesoamerican jaguar habitat. Moreover, high levels of corruption and organized crime, linked to drug trafficking, may facilitate IWT (van Uhm and Moreto, 2018; Zimmerman, 2003). Both countries have recently been implicated in high-profile IWT cases, including scarlet macaws (Ara macao) and rosewood (Dalbergia spp.; Guo, 2019; Soberanes, 2019). We focused on the main urban centres of Belize's Cayo, Toledo and Belize districts (Belmopan, Punta Gorda and Belize City, respectively), and Guatemala's Petén, Izabal and Guatemala departments (Flores, Puerto Barrios and Guatemala City, respectively), where most key informants were based (Figure 1).

\subsection{Key informant interviews}

We conducted 41 semi-structured key informant interviews with conservation specialists who were likely to have access to information about jaguar trade and IWT. Key informant interviews are recommended for exploratory studies like this one (Newing, 2011), where the goal was to determine the existence of jaguar trade in these countries, while also obtaining an in-depth understanding on how jaguar trade is viewed and described by conservation specialists. This means that our results are based on the perspectives and knowledge of our interviewees in their geographical areas, and therefore not transferable beyond these locations, and are subject to interview biases (Martin et al., 2012). We used semi-structured interviews with a standard interview guide (Supplementary Information) to maintain comparability across interviews, while also retaining the flexibility to ask follow up questions relevant to each interviewee's expertise (Newing, 2011; Young et al., 2018).

We interviewed key informants from Belize $(n=17)$ and Guatemala $(n=22)$, including jaguar scientists $(n=3)$, wildlife rescue centre directors $(n=4), N G O$ staff involved in jaguar conservation $(n=19)$, protected area managers $(n=5)$, as well as government and law enforcement representatives $(n=10)$, from 20 different institutions. We also interviewed two people based in Honduras through Skype to gain a broader picture of the position of Belize and Guatemala in regional trade. We first identified key informants through an internet search of IWT cases and jaguar conservation initiatives in both countries, focusing on academic publications, grey literature and news reports. We also consulted our local partners, WCS Mesoamerica, to ensure that we had a comprehensive list of participants working on these topics. We approached 48 potential key informants by email and invited them to suggest additional people within their network who may be knowledgeable on the subject under investigation, adding five people to the list through snowball sampling. Out of 53 people contacted, 41 agreed to participate and were interviewed in person $(n=36)$ or via Skype $(n=5)$ by the lead author from September-November 2018. The one-hour interviews were audio-recorded upon obtaining written or oral consent from participants, but participant identity is kept confidential. The study was approved by the Central University Research Ethics Committee of Oxford University (Reference number: R59134/RE001).

We began the interviews with an open-ended discussion of the key informant's experience working with jaguars, human-jaguar conflict, or IWT more generally. Then, interviewees discussed jaguar trade incidents that they were aware of, making specific reference to; the circumstances leading to jaguar killing, the routes and markets for jaguar items, as well as the characteristics and motivations 
of those involved in jaguar trade. We also asked interviewees to describe the law enforcement processes relating to IWT in their geographic areas of expertise, as well as the institutional strengths and weaknesses affecting this issue (Supplementary Information). Interviewees were prompted to state how certain or uncertain they felt about each specific answer.

\subsection{Interview analysis}

The lead author annotated, transcribed and coded all interviews using NVivo qualitative data analysis software (QSR International Pty Ltd. Version 12 Pro, 2018). We created an initial set of hierarchical thematic nodes (also referred to as thematic codes), based on the interview questions, while other thematic nodes and sub-nodes were added inductively through the iterative coding process based on the interview responses. In order to test the reliability of our coding, another member of the research team coded a randomly selected $10 \%$ of the interviews. Following initial independent coding, the two coders discussed reasons for any discrepancies and then independently recoded the sample. We used the Cohen's Kappa statistic to test for inter-coder consistency in this recoding, which had a value of 0.89 or excellent agreement. Following the guidelines for thematic analysis offered by Braun and Clarke, (2006), Newing, (2011) and Saldana, (2016), we then searched for patterns and emerging themes in the data, merging or separating thematic nodes as necessary. Our main top-level thematic categories, which reflect how our interviewees understood the trade and our interpretation of their examples based on key IWT literature, included jaguar trade characteristics (e.g. body parts used, methods used to kill and trade, and routes), actor types and motivations (with reference to published IWT typologies, including; Muth and Bowe, 1998; Phelps et al., 2016; Thomas-Walters et al., 2019), drivers and enabling factors of jaguar trade. We defined the latter two as "forces, conditions or factors that lead people to behave in a particular way" (TRAFFIC, 2008) and that influence jaguar trade directly and indirectly, respectively.

Where relevant, we present results in terms of number of participants who mentioned a specific theme, or the number of references made by the interviewees on a particular theme. A "reference" is an individual comment, opinion, or a specific instance of jaguar trade given by an interviewee. This definition remained consistent throughout the analysis. We ensured that all references that described specific jaguar trade examples were independent of each other by using details like dates, numbers, locations, and product descriptions to exclude any duplicates. By prompting participants to state their certainty in their answers throughout the interview, we were able to separate references into concrete examples or strong beliefs. Concrete examples refer to recent jaguar trade incidents that interviewees personally witnessed or heard about from a trusted source (e.g. work colleagues or the local communities where they work). We defined "recent" as less than 10 years ago. Strong beliefs are anecdotal accounts, or assumptions made from personal experience without providing specific examples. Whenever the incidents contained geographical information, we geo-referenced them to the nearest town (Figure 1).

\section{Results}

\subsection{Jaguar trade actors}

One set of key players are jaguar body part 'possessors', which broadly encompass subsistence, opportunist, recreational or reactionary harvesters found in Phelps et al., (2016). When they obtain jaguars or their body parts (either actively by harvesting or passively by inheriting or gifting), possessors choose to retain them for their own use, generally as decoration, trophies, or food, without undertaking any financial transaction. Although possessors own jaguar body parts, they are not involved in the jaguar trade chain because they do not sell or buy the body parts. Based on 39 
concrete references (Figure 2), possessors are primarily rural villagers, including farmers, ranchers, hunters and indigenous communities (which sometimes overlap). Although unsubstantiated, one interviewee also strongly believed that members of the Chinese community and regional immigrants acted as possessors. If possessors sell their jaguar body parts, they enter the trade chain, becoming commercial harvesters (suppliers) or intermediaries.

Commercial harvesters or 'suppliers' are people who kill jaguars (or capture live jaguars) and then trade them or their body parts, rather than keeping them. Suppliers belong to similar actor groups as possessors (e.g. rural villagers), but unlike for possessors, regional immigrants (immigrants from neighbouring countries like Honduras, El Salvador) are also included in the supply of jaguar body parts ( $n=3$; Figure 2). Meanwhile, 'intermediaries' transfer jaguar body parts from suppliers to consumers. Although in the majority of the events described, jaguar trade chains were simple, involving a direct transaction between suppliers and consumers (network type " $b$ " in Phelps et al., 2016), there were a few cases which included intermediaries. For example, the tourism sector (including tourist guides, souvenir shops, and resorts) was confirmed to act as a logistical intermediary based on 10 concrete examples, although the demographics of tourist consumers remain unknown (Table 1). In contrast, regional immigrants and drug traffickers were suspected to act as intermediaries $(n=6)$, without concrete evidence. 'Consumers' of jaguar body parts purchase the items from a supplier or intermediary. Although most of the concrete examples of demand for jaguar body parts involved urban elites and wealthier villagers $(n=24)$, the consumer group to which the largest number of references was made was the Chinese community $(n=44)$, even though only $14 \%$ of those references were concrete examples. Another often-mentioned consumer group was other foreigners $(n=7)$, drug traffickers in Guatemala $(n=14)$, as well as tourists $(n=7)$, with varying certainty levels (Figure 2).

\subsection{Motivations for trade}

Our jaguar trade chain starts with the death or trade of a jaguar ( $n=232$ references, of which $52 \%$ were concrete examples), which can occur for commercial (13\%) or non-commercial purposes (41\%), or with no explicit motivation (46\%; Figure 3 ). When a jaguar is specifically targeted and killed for commercial gain, its body parts are intentionally traded. Non-commercial targeted killing $(n=96)$ includes protection of self and property (e.g. animals killed in retaliation for livestock losses, 58\%), recreational satisfactions, trophy poaching or thrill killing (6\%) or due to fear (4\%). Jaguars can also be killed during opportunistic encounters with hunters (31\%). Those involved in non-commercial targeted or opportunistic jaguar killing must then decide whether to: abandon the carcass or report it to the authorities ( $n=23$ ); engage in opportunistic trading, becoming suppliers ( $n=107)$; or keep the parts for personal use, becoming possessors $(n=69)$.

According to the interviews, the motivations for either purchasing or keeping jaguar body parts are quite similar (shared motivations, $\mathrm{n}=176$ ). In most cases, jaguar teeth and skins are used for ornamental purposes such as personal and home decoration, as trophies and symbols of bravery and power (64\%). Other shared motivations include food consumption (19\%), spiritual or cultural beliefs (such as traditional dances, $5 \%$ ), medicine for muscle pain and rheumatism (jaguar fat, $3 \%$ ), or relational purposes (9\%). Motivations that were unique to consumers $(n=31)$ were keeping jaguars in private collections or zoos (52\%), purchasing gifts or souvenirs (42\%), or 'rescuing' cubs out of pity $(6 \%)$. Meanwhile, the only motivation that was unique to possessors $(n=2)$ was using jaguar fat for repelling crop-raiding animals. Commercial jaguar killing, trading and purchasing were not only less common than their non-commercial equivalents, but also more uncertain, having a larger proportion of strong beliefs than concrete examples (Figure 3). 
Of the 232 references in Figure 3, 34\% referred to teeth, followed by skin (20\%), live animals (20\%), meat (16\%), complete carcasses (6\%), claws and paws (2\%), fat (1\%) and bones (1\%). The prices of jaguar body parts, which were described by 13 interviewees, were highly variable. Jaguar teeth ranged from US\$5 to US\$250, depending on whether they were raw or worked (e.g. carved or set), their geographical distance to markets and buyers, and on the supplier's understanding of the market. This vast price difference indicates that a large portion of the profits from selling jaguar teeth is likely to accrue to the intermediaries rather than to the rural suppliers. Eight interviewees had either personally witnessed a jaguar-skinning event or had confiscated jaguar skins, which had an average price of US\$120. Jaguar meat consumption was also mentioned, with five interviewees having witnessed villagers selling jaguar meat, and one having personally eaten jaguar organs (more than 10 years ago);

"as a blessing, so that nobody will try to harm you, and you will be brave enough, and nobody will let you down. You will speak up and become a good leader and roam the area without being afraid of anything that you encounter" (I34).

One interviewee also mentioned that Maya communities traditionally use jaguar paws and bones to heal rheumatism and joint pain, and jaguar fat to keep crop raiding wildlife away from farms. Although unconfirmed, six interviewees had heard that specific Chinese restaurants in Belize are selling jaguar meat and paying hunters up to US\$1000 for a jaguar carcass. Finally, six interviewees provided recent concrete examples of wild-origin jaguar cubs that were traded as pets or kept as attractions in private collections, zoos or circuses. Only one interviewee was familiar with the price of live jaguar cubs, which was US\$325.

\subsection{Strategies for killing and trading jaguars}

According to our interviewees, the methods used to kill jaguars include shooting them during bushmeat hunting trips, especially when hunting dogs are used ( $n=30$ interviewees), using the carcasses of previously-attacked livestock as bait $(n=11)$, poisoning $(n=4)$ and trapping $(n=1)$. Seven interviewees anecdotally stated that when ranchers are unable to kill jaguars themselves, they hire professional jaguar hunters.

Many interviewees felt that trade in jaguar body parts is mostly opportunistic (Figure 3), with suppliers or intermediaries approaching potential buyers on the streets, at home, or in physical or online markets. In fact, 14 interviewees had themselves observed or seized jaguar body parts at physical markets or from street vendors. Additionally, nine interviewees had been actively monitoring social media groups after finding offers of jaguar body parts online. Another strategy is for consumers to place an order with intermediaries, or directly with suppliers, with 8 concrete examples of this behaviour. There were also six confirmed instances where jaguar body parts were exchanged as gifts or inheritance among networks of friends or relatives.

Nine interviewees believed that the trade in jaguar body parts is likely to follow the same routes as other species like macaws or rosewood. Interviewees suspected that jaguar trading routes include the roads coming out of Petén and Izabal to Guatemala City, and from Belize's southern district of Toledo towards the central and northern districts (Figure 1). An interviewee provided a concrete example highlighting southern Belize as a source of jaguar body parts for Guatemala. Given that several jaguar body part seizures have taken place on tourist islands off the coast of Belize and Honduras, there must be a trade route from mainland ports to the islands. Interviewees mentioned only two unconfirmed examples of international trade of jaguar body parts. However, the fact that jaguar body parts are sold to foreign tourists suggests that the items are transported overseas. 


\subsection{Main drivers and enabling factors of jaguar trade}

Our thematic analysis revealed several perceived drivers and enabling factors of jaguar trade. In order of reference frequency, the two main drivers of jaguar trade were human-jaguar conflict and opportunistic hunting (while hunting for bushmeat), although concrete examples comprised only $23 \%$ of the conflict-related references $(n=115)$ and $29 \%$ of hunting events $(n=22$; Table 1$)$. Humanjaguar conflict was strongly believed to be a gateway to jaguar trade, with local communities using lethal control of livestock-eating jaguars to prevent future attacks and to receive financial compensation by selling the jaguar's body parts. While jaguars are not a targeted bushmeat species, interviewees believed that jaguars are likely to be killed whenever they are found by bushmeat hunters. Bushmeat hunting was also thought to drive jaguar trade indirectly by accentuating humanjaguar conflict due to prey depletion. Asian demand was the third most referred-to driver $(n=38)$, but with only $13 \%$ concrete examples (pertaining to requests from people of Chinese descent to local communities).

Drug trafficking was the fourth most-cited driver of jaguar trade $(n=36)$, particularly in Guatemala, where five concrete examples of drug traffickers owning jaguars or jaguar body parts (including the seizure of a taxidermied jaguar during a 2016 drugs raid) were provided. The majority of Guatemalan respondents strongly believed that drug traffickers are involved in jaguar trade because jaguar trophies are a symbol of status, and because they have been involved in financing other types of IWT. The fifth driver of jaguar trade was human migration from neighbouring Central American countries $(n=34)$. These immigrants were perceived as having a stronger hunting and ranching culture, which may lead them to play a role in the jaguar trade chain as suppliers and traders, although this remained largely unsubstantiated (Figure 2). Interviewees also emphasized the potential role of illegal incursionists along the border as suppliers of jaguar body parts. Finally, tourism was the sixth most prevalent $(n=18)$ driver of jaguar trade. It was the most evidenced driver, mainly because the majority of actual seizures of jaguar body parts occurred in well-known tourist destinations (Figure 1).

Overall, except for tourism, drivers of jaguar trade were based more on strong beliefs than concrete examples, but those involving Chinese traders, drug traffickers, and regional immigrants were considerably less well-evidenced (Table 1 ).

We identified eight enabling factors of jaguar trade (Table 2), which make the trade feasible and limit the ability of conservation institutions to respond effectively. The main challenge to conservation institutions was felt to be a lack of financial, human and physical resources ( $n=75$ ). Interviewees perceived that wildlife authorities in both countries did not receive enough attention or financial resources from the central government and were critically underfunded and understaffed. Lack of simple resources like vehicles and fuel constantly jeopardized effective law enforcement. Interviewees also mentioned the ineffectiveness of the law enforcement system $(n=60)$, which is disrupted to the point of inaction by lack of political will, interests behind political decision-making, administrative bureaucracy and excessive staff rotations. A third enabling factor is the animosity and abandonment in the relationship between the government and local communities $(n=47)$. In particular, interviewees claimed that, given a history of prohibitive policies, there is no trust between local communities and wildlife authorities, and attempts to mitigate human-wildlife conflict or conduct enforcement activities often end in violence. The fourth issue identified was corruption among law enforcement authorities, who were believed to collaborate with wildlife traders $(n=45)$.

Outdated legal systems and the lack of seriousness with which IWT cases are treated was the fifth enabling factor $(n=22)$. Laws were not only deemed antiquated, but filled with loopholes and with weak penalties. IWT is not typified as a serious crime, limiting the types of evidence that can be 
presented to court, and bounding the range of action of judges. The sixth enabling factor was the lack of capacity of wildlife authorities and conservation organizations to conduct intelligence investigations to enable successful sentencing $(n=20)$, given the technical challenges of identifying the origins of confiscated items. NGOs and wildlife authorities constantly had to go beyond their responsibilities and expertise to aid prosecutors in their investigations. The seventh enabling factor was the lack of mandate of unarmed park rangers, wildlife authorities and NGOs to enforce the law $(n=16)$, including conducting seizures or apprehending wildlife traffickers. Interviewees regretted spending too much time and effort trying to mobilize partner institutions with a stronger mandate such as the police, the military, the Ministry of Defence or the Public Ministry. The final enabling factor was the lack of safety for those conducting law enforcement operations on the ground $(n=9)$. Given that enforcement efforts are unlikely to lead to imprisonment of traffickers, many interviewees feared retaliation from criminals, highlighting previous assassinations of conservationists and park rangers.

\section{Discussion}

While jaguar trade is certainly present in Belize and Guatemala, our interviews suggest that it is mainly an opportunistic activity, enabled by domestic socioeconomic and institutional factors rather than driven by international trade. This is in contrast with the discourse that dominates the broad field of IWT, characterising it as a transnational organized crime, involving criminal rings with complex, mafia-style hierarchical structures parallel to those for drugs and human trafficking. This characterisation has served as justification for the militarisation of conservation (Duffy, 2014), and is mainly based on the sophisticated and expensive strategies and technologies sometimes used by illegal ivory and rhino horn traders (Wasser et al., 2008). This narrative has been applied to a range of traded species, even when there is no conclusive evidence (Pires et al., 2016). It may be appealing because it establishes the severity of the problem, helping to attract attention and resources into combating IWT (Runhovde, 2018). However, it often conflates subsistence and commercial forms of "extra-legal" hunting, ignoring the root drivers and enabling factors of IWT, breaching human rights, criminalizing local livelihoods, and turning local communities against wildlife (Duffy et al., 2016; Mabele, 2017).

Even though jaguar killing and trading is not a new phenomenon, it was not until its ties with Chinese demand became evident that the media and the conservation community started to pay attention, decrying its potential ties to tiger trade, Chinese investments, and organized crime (Morcatty et al., 2020; Navia, 2018; Yagoub, 2016). While jaguar trade may be more akin to organized crime or more linked to Chinese investments in other Latin American countries, our findings do not corroborate this hypothesis for Belize and Guatemala. Indeed, jaguar trade in these countries does not appear to meet any of the proposed criteria of 'organized crime', including criminal sophistication (planning and skill), structure (division of labour), self-identification, and authority of reputation (intimidation; Finckenauer, 2005; Pires et al., 2016). Instead, the majority of concrete examples provided by our interviewees portrayed jaguar trade as a domestic, sporadic and opportunistic endeavour, carried out primarily by non-specialized, self-recruited rural villagers with no apparent affiliations to wider criminal networks. However, we acknowledge that our results are based on a small sample of key informants who, despite working with these issues on the ground, may have a restricted or biased understanding of jaguar trade in their areas. Therefore, a more comprehensive characterisation of jaguar trade in these countries would require further studies targeting actors involved in the trade, with larger sample sizes.

Also contrasting with the general perception that consumers drive IWT, jaguar trade in Belize and Guatemala appears to be supply-driven. In supply-driven markets, few barriers to entry, resource scarcity, and opportunity costs influence suppliers' decisions to participate in the market independently of price signals, constraining consumer choice (McNamara et al., 2016). Sharing a vast 
landscape with the species, jaguar suppliers have few barriers to enter the market, requiring no special skills aside from those already possessed by communities with a strong hunting and ranching tradition. Jaguars occur at low densities (around 2.5 individuals per $100 \mathrm{~km} 2$ in Belize and Guatemala; Jędrzejewski et al., 2018), potentially limiting suppliers' participation in the market and accessibility of products to consumers. However, in contrast to typical supply-driven wildlife markets, in which resource scarcity leads to higher prices to the detriment of the consumer (McNamara et al., 2016), the prices of jaguar body parts varied widely and were often lower than reported in other Latin American countries. Low prices suggest that the demand may itself be limited, while price variation suggests that jaguar suppliers and traders may be unaware of market prices, or even the existence of markets. However, the increasing recognition of the potential role of people of Chinese descent, drug traffickers, regional immigrants and tourists in jaguar trade, which was reflected in our interviews, might be indicative of a transition towards a demand-driven system. A larger, wealthier and steadier consumer base may encourage intermediaries into the jaguar trade chain and spread price information to suppliers, pushing more people to intentionally search for jaguars, potentially using the specialized jaguar traps or baiting methods previously employed to hunt jaguars at a commercial scale.

The contrast between the discourse about IWT and the characteristics of jaguar trade in Belize and Guatemala suggested by our interviews, speaks to the importance of separating real evidence from assumptions. Our analysis distinguished between events witnessed by participants or their trusted sources, and assumptions originating from second-hand or anecdotal information. This distinction uncovered the central role of local actors and opportunistic motivations in the jaguar trade, despite the largely-unsubstantiated weight given to external actors and organized crime structures during the interviews. Our results suggest that conservation efforts and investments should consider uncertainty and target well-evidenced actors, motivations and drivers of trade in order to be confident of having an impact.

Conservation actions to reduce jaguar trade in Belize and Guatemala should focus on building incentives for local jaguar conservation amongst rural villagers, who were identified as major actors at multiple levels of the trade chain. Drawing on Cooney et al., (2017), approaches could include promoting jaguar tourism (Tortato et al., 2017), reducing the costs of human-jaguar conflict (Quigley et al., 2015), reducing the social acceptability and prestige of killing (Knox et al., 2019), or increasing the costs of jaguar hunting by addressing the enabling factors that we have outlined. The assumptions made by our interviewees may be indicative of unfolding processes which deserve attention. The potential role of the Chinese community, drug traffickers and regional immigrants in transforming jaguar trade into a profitable demand-driven endeavour should be further explored, but taking care not to make oversimplified judgements about the 'other', which have proliferated within the field of IWT (Margulies et al., 2019).

\section{Acknowledgements}

We thank the Wildlife Conservation Society (WCS), especially K. Duchez, L. McLoughlin, J. Polisar, J. Radachowsky and A. Reuter, for funding and supporting this work. The lead authors thanks F. Arana Meira and J. Goetschel for their valuable input to this research, and PhD funding bodies, SENESCYT, Wildlife Conservation Society and the Wildlife Conservation Network. We thank the Belize Forest Department (Reference Number: WL/2/1/18(34)) and Guatemala's CONAP (Of.DMBVS-585-2018) for granting us permission to conduct this research in Belize and Guatemala. We also thank the Central University Research Ethics Committee (CUREC) at the University of Oxford for reviewing this research and granting their ethical approval (Reference number: R59134/RE001).

Funding: This work was supported by the United States Department of the Interior ("DOI") and the United States Fish and Wildlife Service ("USFWS") under the terms of Assistance Award \# FI 
404 7ACOO419 to the Wildlife Conservation Society; the Oxford Martin Programme on the Illegal Wildlife 405 Trade; SENESCYT; Wildlife Conservation Society Christensen Conservation Leaders Scholarship; and 406 the Wildlife Conservation Network Graduate Scholarship. The content and opinions expressed 407 herein are those of the authors and do not necessarily reflect the position or the policy of the DOI, 408 USFWS or WCS and no official endorsement should be inferred. The funding bodies had no 409 involvement in the study design; in the collection, analysis and interpretation of data; in the writing 410 of the report; and in the decision to submit the article for publication. 


\section{References}

Braun, V., Clarke, V., 2006. Using thematic analysis in psychology. Qual. Res. Psychol. 3, 77-101. https://doi.org/10.1191/1478088706qp063oa

Briones-Salas, M., Lavariega, M.C., Lira-Torres, I., 2012. Present and potential distribution of the jaguar (Panthera onca) in Oaxaca, Mexico. Rev. Mex. Biodivers. 83, 246-257.

CITES, 2017. Appendices I, II and III [WWW Document]. URL https://cites.org/eng/app/appendices.php (accessed 9.24.18).

Cooney, R., Roe, D., Dublin, H., Phelps, J., Wilkie, D., Keane, A., Travers, H., Skinner, D., Challender, D.W.S., Allan, J.R., Biggs, D., 2017. From Poachers to Protectors: Engaging Local Communities in Solutions to Illegal Wildlife Trade. Conserv. Lett. 10, 367-374. https://doi.org/10.1111/conl.12294

Duffy, R., 2014. Waging a war to save biodiversity: the rise of militarized conservation. Int. Aff. 90, 819-834. https://doi.org/10.1111/1468-2346.12142

Duffy, R., St John, F.A. V., Büscher, B., Brockington, D., 2016. Toward a new understanding of the links between poverty and illegal wildlife hunting. Conserv. Biol. 30, 14-22. https://doi.org/10.1111/cobi.12622

Figel, J.J., Ruíz-Gutiérrez, F., Brown, D.E., 2016. Densities and perceptions of jaguars in coastal Nayarit, Mexico. Wildl. Soc. Bull. 40, 506-513. https://doi.org/10.1002/wsb.686

Finckenauer, J.O., 2005. Problems of definition: What is organized crime? Trends Organ. Crime 8, 63-83. https://doi.org/10.1007/s12117-005-1038-4

Guo, E., 2019. The fight to protect the world's most trafficked wild commodity [WWW Document]. URL https://www.nationalgeographic.com/animals/2019/08/guatemala-fight-againstrosewood-trafficking/ (accessed 12.20.19).

Harmsen, B., Urbina, Y., 2017. Wildlife Use in Belize. Belize City.

Harrison, M., Roe, D., Baker, J., Mwedde, Geoffrey Travers, H., Plumptre, A., Rwetsiba, A., MilnerGulland, E.J., 2015. Wildlife crime: a review of the evidence on drivers and impacts in Uganda. London. https://doi.org/ISBN 978-1-78431-179-7

Inskip, C., Zimmermann, A., 2009. Human-felid conflict: A review of patterns and priorities worldwide. ORYX. https://doi.org/10.1017/S003060530899030X

Jędrzejewski, W., Robinson, H.S., Abarca, M., Zeller, K.A., Velasquez, G., Paemelaere, E.A.D., Goldberg, J.F., Payan, E., Hoogesteijn, R., Boede, E.O., Schmidt, K., Lampo, M., Viloria, Á.L., Carreño, R., Robinson, N., Lukacs, P.M., Nowak, J.J., Salom-Pérez, R., Castañeda, F., Boron, V., Quigley, H., 2018. Estimating large carnivore populations at global scale based on spatial predictions of density and distribution - Application to the jaguar (Panthera onca). PLoS One 13, e0194719. https://doi.org/10.1371/journal.pone.0194719

Kahler, J.S., Gore, M.L., 2017. Conservation Crime Science, in: Conservation Criminology. John Wiley \& Sons, Ltd, pp. 25-43. https://doi.org/10.1002/9781119376866.ch2

Kelly, J.R., 2018. Insights into the illegal trade of feline derivatives in Costa Rica. Glob. Ecol. Conserv. 13. https://doi.org/10.1016/J.GECCO.2018.E00381

Knox, J., Negrões, N., Marchini, S., Barboza, K., Guanacoma, G., Balhau, P., Tobler, M.W., Glikman, J.A., 2019. Jaguar Persecution Without "Cowflict": Insights From Protected Territories in the Bolivian Amazon. Front. Ecol. Evol. 7, 494. https://doi.org/10.3389/fevo.2019.00494 
Laffoon, J.E., Rodríguez Ramos, R., Chanlatte Baik, L., Narganes Storde, Y., Rodríguez Lopez, M., Davies, G.R., Hofman, C.L., 2014. Long-distance exchange in the precolonial Circum-Caribbean: A multi-isotope study of animal tooth pendants from Puerto Rico. J. Anthropol. Archaeol. 35, 220-233. https://doi.org/10.1016/J.JAA.2014.06.004

Lemieux, A.M., Bruschi, N., 2019. The production of jaguar paste in Suriname: a product-based crime script. Crime Sci. 8, 6. https://doi.org/10.1186/s40163-019-0101-4

Mabele, M.B., 2017. Beyond forceful measures: Tanzania's 'war on poaching' needs diversified strategies more than militarised tactics. Rev. Afr. Polit. Econ. 44, 487-498. https://doi.org/10.1080/03056244.2016.1271316

Margulies, J.D., Wong, R.W.Y., Duffy, R., 2019. The imaginary 'Asian Super Consumer': A critique of demand reduction campaigns for the illegal wildlife trade. Geoforum. https://doi.org/10.1016/j.geoforum.2019.10.005

Martin, T.G., Burgman, M.A., Fidler, F., Kuhnert, P.M., Low-Choy, S., McBride, M., Mengersen, K., 2012. Eliciting Expert Knowledge in Conservation Science. Conserv. Biol. 26, 29-38. https://doi.org/10.1111/j.1523-1739.2011.01806.x

May, C., Clough, C., 2017. Transnational Crime and the Developing World. Glob. Financ. Integr.

McNamara, J., Rowcliffe, M., Cowlishaw, G., Alexander, J.S., Ntiamoa-Baidu, Y., Brenya, A., MilnerGulland, E.J., 2016. Characterising Wildlife Trade Market Supply-Demand Dynamics. PLoS One 11, e0162972. https://doi.org/10.1371/journal.pone.0162972

Morcatty, T.Q., Bausch Macedo, J.C., Nekaris, K.A., Ni, Q., Durigan, C.C., Svensson, M.S., Nijman, V., 2020. Illegal trade in wild cats and its link to Chinese-led development in Central and South America. Conserv. Biol. cobi.13498. https://doi.org/10.1111/cobi.13498

Muth, R.M., Bowe, J.F., 1998. Illegal harvest of renewable natural resources in North America: Toward a typology of the motivations for poaching. Soc. Nat. Resour. 11, 9-24. https://doi.org/10.1080/08941929809381058

Navia, R., 2018. Fang trafficking to China is putting Bolivia's jaguars in jeopardy. Mongabay.

Nellemann, C., Henriksen, R., Raxter, P., Ash, N., Mrema, E. (Eds), 2014. The Environmental Crime Crisis - Threats to Sustainable Development from Illegal Exploitation and Trade in Wildlife and Forest Resources. A UNEP Rapid Response Assessment.

Newing, H., 2011. Conducting Research in Conservation: Social Science Methods and Practice. Routledge. https://doi.org/10.4324/9780203846452

Nunez, A.M., Aliaga-Rossel, E., 2017. Jaguar fangs trafficking by Chinese in Bolivia. CAT News 65.

Phelps, J., Biggs, D., Webb, E.L., 2016. Tools and terms for understanding illegal wildlife trade. Front. Ecol. Environ. 14, 479-489. https://doi.org/10.1002/fee.1325

Pires, S.F., Schneider, J.L., Herrera, M., 2016. Organized crime or crime that is organized? The parrot trade in the neotropics. Trends Organ. Crime 19, 4-20. https://doi.org/10.1007/s12117-0159259-7

Quigley, H., Foster, R., Petracca, L., Payan, E., Salom, R., Harmsen, B., 2017. Panthera Onca. IUCN Global Species Programme Red List Unit. https://doi.org/e.T15953A50658693

Quigley, H.B., Hoogesteijn, R., Hoogesteijn, A., Foster, R.J., Payan, E., Corrales, D., Salom-Pérez, R., Urbina, Y., 2015. Observations and preliminary testing of jaguar depredation reduction techniques in and between core jaguar populations. PARKS 21. 
Reuter, A., Kunen, J., Roberton, S., 2018a. Averting a Crisis: Wildlife Trafficking in Latin America. New York, NY.

Reuter, A., Maffei, L., Polisar, J., Radachowsky, J., Montefiore, A., de la Torre, A., Mario Orrego, C., Corrales-Gutiérrez, D., Enrique Simá, D., Carrillo, E., Ponce Santizo, G., Portillo Reyes, H., Zarza Villanueva, H., Ortega, J., Pablo Suazo, J., Moreno, J., McLoughlin, L., Fonseca Lopez, L., Mérida, M., Meyer, N., Oropeza Hernández, P., Moreno, R., Salom-Pérez, R., Núñez, R., Amit, R., García Anleu, R., Hernández Potosme, S., Arroyo Arce, S., Urbina, Y., 2018b. Jaguar Hunting and Trafficking in Mesoamerica Recent Observations.

Runhovde, S.R., 2018. Merely a transit country? Examining the role of Uganda in the transnational illegal ivory trade. Trends Organ. Crime 21, 215-234. https://doi.org/10.1007/s12117-0169299-7

Saldana, J., 2016. The Coding Manual for Qualitative Researchers, 3rd ed. Sage Publications, London.

Sanderson, E.W., Forrest, J., Loucks, C., Ginsberg, J., Dinerstein, E., Seidensticker, J., Leimgruber, P., Songer, M., Heydlauff, A., O’Brien, T., Bryja, G., Klenzendorf, S., Wikramanayake, E., 2010. Setting Priorities for Tiger Conservation: 2005-2015, in: Tigers of the World. Elsevier Inc., pp. 143-161. https://doi.org/10.1016/B978-0-8155-1570-8.00009-8

Saunders, N.J., 1998. Icons of power : feline symbolism in the Americas. Routledge.

Soberanes, R., 2019. Wildlife traffickers thrive on Guatemala's murky border with Belize [WWW Document]. Mongabay. URL https://news.mongabay.com/2019/03/wildlife-traffickers-thriveon-guatemalas-murky-border-with-belize/ (accessed 12.20.19).

T Sas-Rolfes, M., Challender, D.W.S., Hinsley, A., Veríssimo, D., Milner-Gulland, E.J., 2019. Illegal Wildlife Trade: Scale, Processes, and Governance. Annu. Rev. Environ. Resour. 44, 201-228. https://doi.org/10.1146/annurev-environ-101718-033253

Thomas-Walters, L., Hinsley, A., Bergin, D., Doughty, H., Eppel, S., MacFarlane, D., ... Veríssimo, D., 2019. Motivations for the use and consumption of wildlife products. SocArXiv. https://doi.org/https://doi.org/10.31235/osf.io/7vjrg

Tortato, F.R., Izzo, T.J., Hoogesteijn, R., Peres, C.A., 2017. The numbers of the beast: Valuation of jaguar (Panthera onca) tourism and cattle depredation in the Brazilian Pantanal. Glob. Ecol. Conserv. 11, 106-114. https://doi.org/10.1016/J.GECCO.2017.05.003

TRAFFIC, 2008. What's Driving the Wildlife Trade? A Review of Expert Opinion on Economic and Social Drivers of the Wildlife Trade and Trade Control Efforts in Cambodia, Indonesia, Lao PDR and Vietnam. Washington DC.

UNODC, 2016. World Wildlife Crime Report: Trafficking in protected species.

van Uhm, D.P., Moreto, W.D., 2018. Corruption Within the Illegal Wildlife Trade: A Symbiotic and Antithetical Enterprise. Br. J. Criminol. 58, 864-885. https://doi.org/10.1093/bjc/azx032

Verheij, P., 2019. An Assessment of Wildlife Poaching and Trafficking in Bolivia and Suriname. Amsterdam.

https://doi.org/https://www.iucn.nl/files/publicaties/an_assessment_of_wildlife_poaching_an d_trafficking_in_bolivia_and_suriname.pdf

Wasser, S.K., Joseph Clark, W., Drori, O., Stephen Kisamo, E., Mailand, C., Mutayoba, B., Stephens, M., 2008. Combating the illegal trade in African elephant ivory with DNA forensics. Conserv. Biol. 22, 1065-1071. https://doi.org/10.1111/j.1523-1739.2008.01012.x

Wittemyer, G., Northrup, J.M., Blanc, J., Douglas-Hamilton, I., Omondi, P., Burnham, K.P., 2014. 
Illegal killing for ivory drives global decline in African elephants. Proc. Natl. Acad. Sci. U. S. A. 111, 13117-21. https://doi.org/10.1073/pnas.1403984111

Yagoub, M., 2016. Chinese Smugglers Driving Up Jaguar Killings in Bolivia. InSight Crime. https://doi.org/https://www.insightcrime.org/news/brief/chinese-smugglers-drive-up-jaguarkillings-in-bolivia/

Young, J.C., Rose, D.C., Mumby, H.S., Benitez-Capistros, F., Derrick, C.J., Finch, T., Garcia, C., Home, C., Marwaha, E., Morgans, C., Parkinson, S., Shah, J., Wilson, K.A., Mukherjee, N., 2018. A methodological guide to using and reporting on interviews in conservation science research. Methods Ecol. Evol. 9, 10-19. https://doi.org/10.1111/2041-210X.12828

Zimmerman, M.E., 2003. The Black Market for Wildlife: Combating Transnational Organized Crime in the Illegal Wildlife Trade. Vanderbilt J. Transnatl. Law 36, 1657-1690.

https://doi.org/https://heinonline.org/HOL/Page?handle=hein.journals/vantl36\&div=64\&g_se $\mathrm{nt}=1 \&$ casa_token $=\&$ collection $=$ journals 


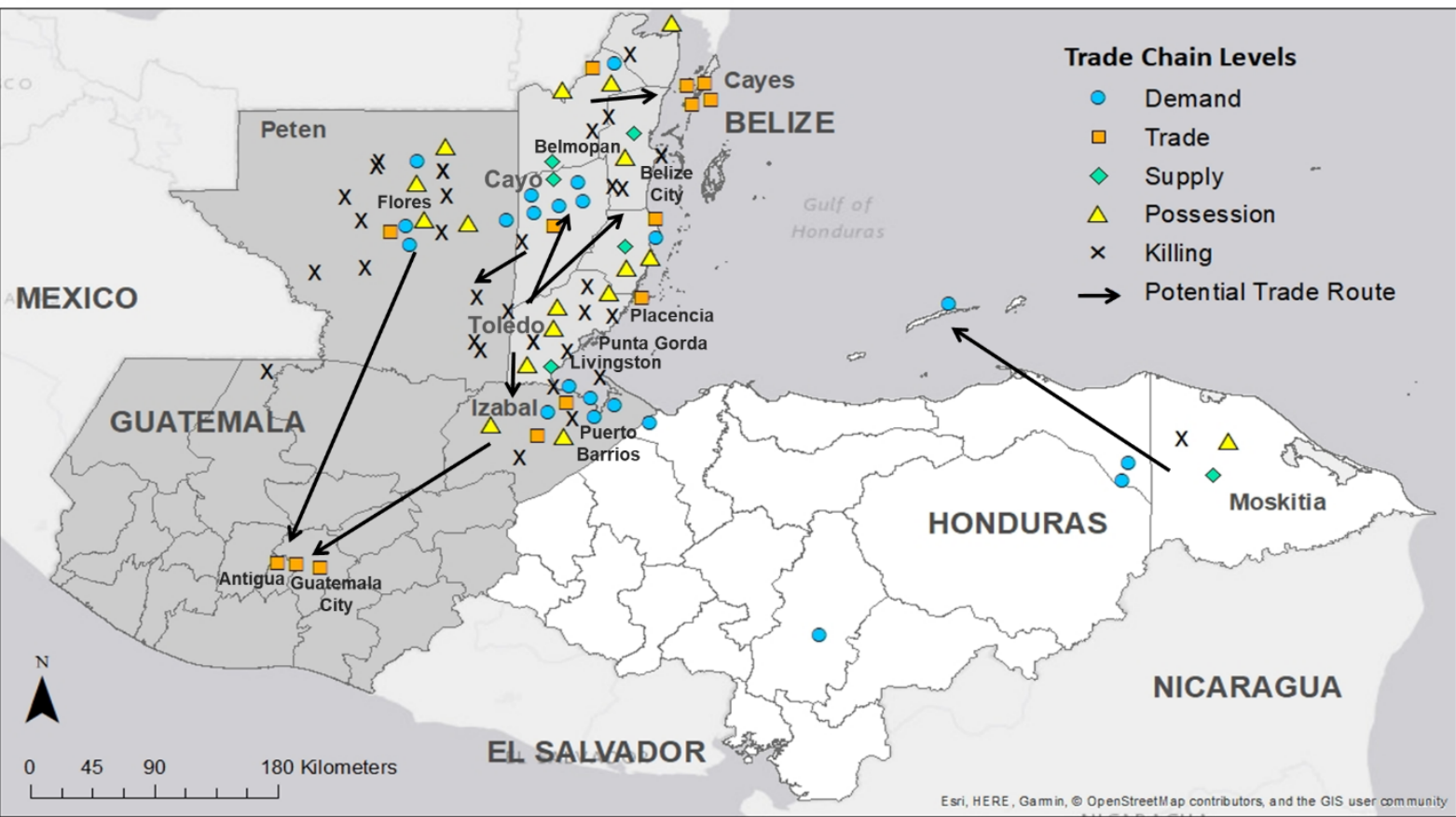

Figure 1: Map of geographically-specified (with point offset) concrete and anecdotal jaguar trade incidents according to the levels of the jaguar trade chain, with arrows showing potential jaguar trade routes. Interviews took place in Guatemala City, Flores, Belmopan, Belize City, Punta Gorda and Puerto Barrios.

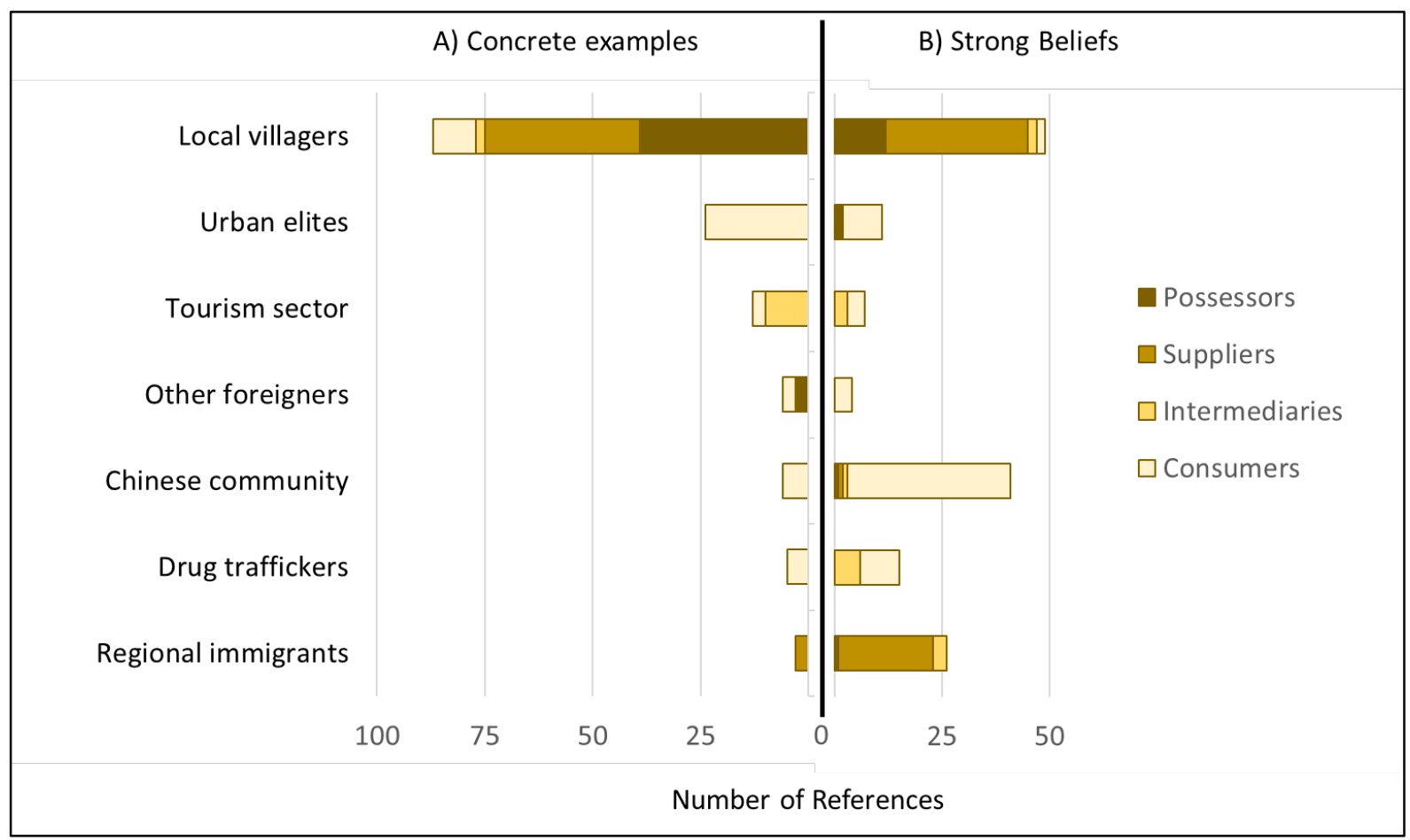

Figure 2: Number of references (independent comments, $n=297$ ) made by 38 interviewees to the characteristics of jaguar body part possessors, suppliers, intermediaries and consumers, separated by concrete examples (Panel A) and strong beliefs (Panel B). 


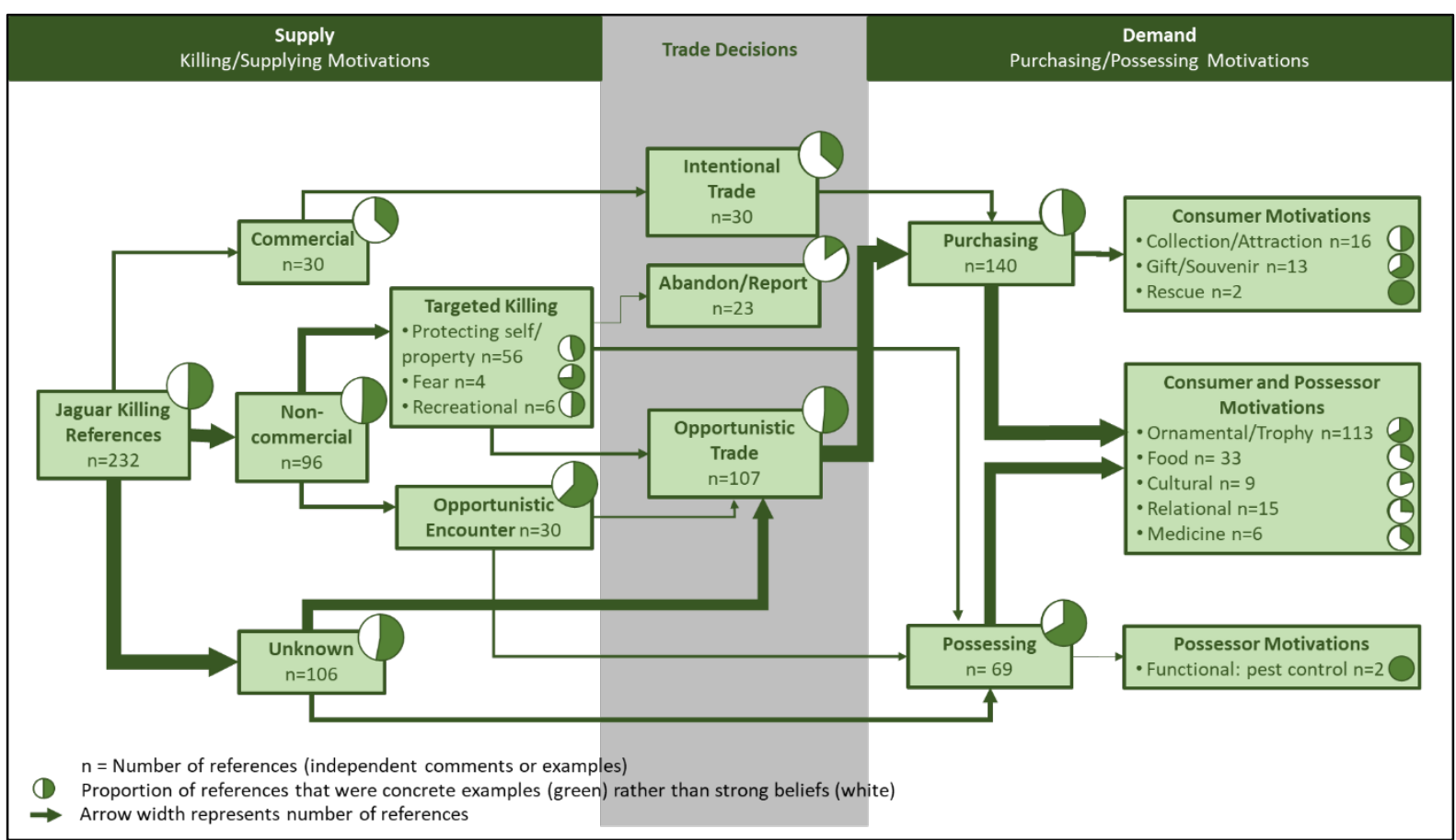

Figure 3: Flowchart of jaguar trading motivations based on the number of recent (<10 years), independent jaguar killing references $(n=232)$ made by interviewees $(n=35)$, including uncertainty, represented in circles.

Table 1: Drivers of jaguar trade, listed in order of the number of interviewees who mentioned the theme. Number of interviewees and number of references (comments, opinions or examples) to the theme are given in parentheses. Uncertainty in the references is presented within the circles as the proportion of concrete examples (green) vs. strong beliefs (white).

\begin{tabular}{|c|c|}
\hline $\begin{array}{l}\text { DRIVERS } \\
\text { (\# of } \\
\text { interviewees, } \\
\text { \# references) }\end{array}$ & Key Quotes (Interviewee number) \\
\hline $\begin{array}{l}\text { 1. Human- } \\
\text { jaguar conflict } \\
(40,115)\end{array}$ & $\begin{array}{l}\text { "I believe that jaguar trade here is more reactive. I think it's because the jaguar is giving } \\
\text { problems in the farms, and the residents will hire someone to kill the jaguar. They use } \\
\text { human wildlife conflict as an opportunity to do trade, because the market is there, the } \\
\text { demand is there, so if they have it available, they can definitely find the market" (I6). } \\
\text { "We have a lot of jaguars and the amount of conflict is very high. What is reported is } \\
\text { really just the tip of the iceberg. A lot of them (ranchers) have an attitude of "I'll go back } \\
\text { to shooting because I can actually get some money for it" (I13). }\end{array}$ \\
\hline $\begin{array}{l}\text { 2. Opportunistic } \\
\text { Hunting (33, } \\
76 \text { ) }\end{array}$ & $\begin{array}{l}\text { "In rural areas it's opportunistic, there is no one to do enforcement or do awareness, so } \\
\text { they'll take the chance to take the body parts and sell it and make some kind of profit off } \\
\text { of the jaguar just because they found it while hunting" (I29). } \\
\text { "Here people consume jaguar prey and if there are no more prey the animal (jaguar) will } \\
\text { go hunt animals at people's houses and that's how the conflict begins and they get killed } \\
\text { and that's how the selling of the teeth and skulls begins. It's a connected chain" (I39). }\end{array}$ \\
\hline $\begin{array}{l}\text { 3. Chinese } \\
\text { demand (21, } \\
\text { 48) }\end{array}$ & $\begin{array}{l}\text { "We were getting reports that there was a Chinese guy asking for the meat. We made } \\
\text { the investigation and we knew where the restaurant was. It wasn't for sale, it was more } \\
\text { for their own consumption as a delicacy. If I remember well there were actually hunters } \\
\text { going out to catch jaguars for this Asian" (I6). }\end{array}$ \\
\hline
\end{tabular}




\begin{tabular}{|c|c|}
\hline & $\begin{array}{l}\text { "We responded to a call near the border where people were killing jaguars because they } \\
\text { attack livestock and because of IWT because the Chinese were paying good money for } \\
\text { jaguar teeth or for the whole jaguar" (I32). }\end{array}$ \\
\hline $\begin{array}{l}\text { 4. Drug } \\
\text { trafficking } \\
(18,36)\end{array}$ & $\begin{array}{l}\text { "Something very common in my country is that these men (drug traffickers) love wildlife } \\
\text { and they like having their own zoos. Here we had a case where the largest zoo in the } \\
\text { country belonged to a famous narco. So when I think about their (narco) presence around } \\
\text { protected areas, surely there are people who have been paid to fetch a jaguar" (I21). } \\
\text { "Where I work, the people have told me that they are killing jaguars. What they want are } \\
\text { the teeth and the skins to have as trophies. They like to wear the teeth in golden chains. } \\
\text { That's what narcos like the most" (I41). }\end{array}$ \\
\hline $\begin{array}{l}\text { 5. Migration (12, } \\
34)\end{array}$ & $\begin{array}{l}\text { "The demographics of the population have changed. It was traditionally Mayan } \\
\text { communities, but we have a massive influx of immigrants from Guatemala, Honduras, El } \\
\text { Salvador, so they have a totally different ethic and culture. In Mayan culture, the jaguar } \\
\text { is a revered entity and not for consumption but we are having a loss of tradition" (I22). } \\
\text { "With the population growing and an influx of other Central American people, the people } \\
\text { who hunt these animals. I don't know if they hunt them specifically for the teeth or the } \\
\text { skin but once they kill an animal they will take those things because those have value and } \\
\text { they like to wear the collars" (I28). }\end{array}$ \\
\hline $\begin{array}{l}\text { 6. Tourism (12, } \\
\text { 18) }\end{array}$ & $\begin{array}{l}\text { "The resorts, they will call people in the farms and ask them for jaguar skins. We have just } \\
\text { been informed that it works like that, but we are not sure which resort it is. People tend to } \\
\text { keep that to themselves. He said that there was multiple resorts is not just one" (I3). } \\
\text { "I clearly remember because it was very intriguing to me, there was a particular person } \\
\text { that did report selling jaguar tooth to tourists and he was a tour guide" (II7). }\end{array}$ \\
\hline
\end{tabular}

572 Table 2: Factors enabling jaguar trade, listed in order of the number of interviewees who mentioned 573 the theme. Number of interviewees and number of references (comments, opinions or examples) to 574 the theme are given in parentheses. Table 2 was not coded in terms of the uncertainty of references 575 because very few interviewees gave concrete examples to support their comments on enabling 576 factors, speaking about the issues more generally.

\begin{tabular}{|c|c|}
\hline $\begin{array}{l}\text { Enabling factors } \\
\text { (\# of } \\
\text { interviewees, \# } \\
\text { of references) }\end{array}$ & Key Quotes (Interviewee number) \\
\hline $\begin{array}{l}\text { 1. Lack of } \\
\text { financial, } \\
\text { human and } \\
\text { physical } \\
\text { resources (30, } \\
75)\end{array}$ & $\begin{array}{l}\text { "If we get a call about a jaguar, we cannot go and it's difficult because here we have } \\
\text { limited fuel. We get a small amount of fuel per month and only one vehicle and nationally } \\
\text { we can't do everything because of the fuel limitation" (I20). } \\
\text { "Sometimes we get informed about cases of hunting or illegal wildlife trade, and even in } \\
\text { the cases when we receive an early warning, we have problems to react and we only get } \\
\text { to 5-8\% of the cases given our current resources and capacity to respond" (I27). }\end{array}$ \\
\hline $\begin{array}{l}\text { 2. Ineffectiveness } \\
\text { of Law } \\
\text { Enforcement } \\
\text { Systems (28, } \\
60)\end{array}$ & $\begin{array}{l}\text { "We have authorities that work for conservation but they are not even aware of the } \\
\text { issues because those jobs are politicised and they are seen as a political favour. IWT } \\
\text { affects so many people that when they address it, they lose votes" (I18). } \\
\text { "The administrative systems have become extremely bureaucratic so to respond to a } \\
\text { jaguar case you need to get fuel and you need to do an immense amount of bureaucracy } \\
\text { to respond to those emergencies because those systems are built on lack of trust" (I30). }\end{array}$ \\
\hline
\end{tabular}




\begin{tabular}{|c|c|}
\hline $\begin{array}{l}\text { 3. Government- } \\
\text { community } \\
\text { relationships } \\
(22,47)\end{array}$ & $\begin{array}{l}\text { "Given the lack of governance in protected areas, it is very difficult to act without the } \\
\text { Ministry of Defence because whenever we capture a trader or we seize any wildlife, the } \\
\text { communities rise up and don't allow the authorities to exit. They are very strong" (I1). } \\
\text { "Ranchers are simply killing jaguars and we only find out because we have a large } \\
\text { network. We are trying to address that but we cannot do it directly, because ranchers } \\
\text { don't want to have anything to do with the wildlife authorities. There is simply no trust } \\
\text { and we have to act as silent partners of other organizations" (I39). }\end{array}$ \\
\hline $\begin{array}{l}\text { 4. Corruption } \\
(21,45)\end{array}$ & $\begin{array}{l}\text { "The border control staff have had a lot of training on how to detect products being } \\
\text { transported, including wildlife, but the big problem is that there is a lot of corruption and } \\
\text { if you want to get something out it is possible to do that with the right kind of connections } \\
\text { and a payment of a bribery, and I am confident to say that is the case" (I15). } \\
\text { "My concern here is how can you make the law personnel, the guys on the ground, the } \\
\text { police, the rangers, uphold the law. If those guys are corrupted, you have a problem. You } \\
\text { will find that the authority is sometimes colluding with the illegal wildlife traders" (I28). }\end{array}$ \\
\hline $\begin{array}{l}\text { 5. Outdated legal } \\
\text { systems and } \\
\text { disregarding } \\
\text { wildlife trade } \\
\text { as a non- } \\
\text { serious crime } \\
(12,22)\end{array}$ & $\begin{array}{l}\text { "To reduce IWT the installation of environmental courts is not the absolute recipe because } \\
\text { even if the judges have the will to give strong sentences, the inconsistencies in the law } \\
\text { don't allow it. We need legal reforms to typify environmental matters more seriously" (I7). } \\
\text { "It is difficult with the court system. We have court prosecutors, magistrates, who just } \\
\text { completely refuse to speak with you, because they would say they don't see an interest, } \\
\text { and why would you take someone to court for hunting. They don't see it as an issue" (I20). }\end{array}$ \\
\hline $\begin{array}{l}\text { 6. Lack of } \\
\text { evidence and } \\
\text { intelligence } \\
\text { investigations } \\
(10,20)\end{array}$ & $\begin{array}{l}\text { "We have created fake accounts on social media to get more information from traders, } \\
\text { and we give that to the prosecution office but sometimes they want too many details like } \\
\text { full names, address, ID number, and many processes are dropped because we can't get all } \\
\text { that. We try to investigate, but that is really the responsibility of other agencies" (I5). } \\
\\
\text { "One of the main challenges would be that if you find teeth, you can prove that it's a } \\
\text { jaguar. We were always lobbying to get some sort of genetic lab to actually test these } \\
\text { things. We can only go by experience but in court you have to go with evidence for this } \\
\text { case to be properly prosecuted and be successful" (I6). }\end{array}$ \\
\hline $\begin{array}{l}\text { 7. Lack of } \\
\text { mandate to } \\
\text { enforce the } \\
\text { law }(9,16)\end{array}$ & $\begin{array}{l}\text { "A weakness is that to do law enforcement, you need to bring the prosecution office and } \\
\text { other organizations, but they are never on the ground in the protected areas. It's not like } \\
\text { in other countries where the rangers can carry out the seizures. We can only write a } \\
\text { technical report but we cannot seize, we lack the mandate" (I2). } \\
\text { "The problem is once we have done everything in our hands, it is the responsibility of the } \\
\text { authorities to enforce the law. We don't have jurisdiction and we cannot implement the } \\
\text { law, and it means that sometimes the issues just keep recurring again and again" (I16). }\end{array}$ \\
\hline $\begin{array}{l}\text { 8. Lack of safety } \\
\text { for the } \\
\text { conservation } \\
\text { community (7, } \\
\text { 9) }\end{array}$ & $\begin{array}{l}\text { "We have good people in the government, but many times they are tied due to political } \\
\text { interference and that discourages people, because you don't want to go through all this } \\
\text { effort, and when you get there the person (trader) will laugh at you and walk away. Then } \\
\text { you are the bad guy and you create an enemy for yourself and put yourself at risk" (I10) } \\
\text { "In our country, there is a lot of fear from the authorities to act and there's a lot of } \\
\text { organized crime inside protected areas and the authorities know it but they can't do } \\
\text { anything because of fear. In fact, } 3 \text { years ago, a wildlife officer that was actively working } \\
\text { on environmental crimes was murdered, and that crime remains unpunished" (I21). }\end{array}$ \\
\hline
\end{tabular}




\section{Supplementary Information - Jaguar Trade Interview Guide}

\section{Background and Knowledge on Jaguar Trade}

1. Could you please state your name and nationality?

2. What is your profession and your current institutional affiliation?

3. What is your educational background?

4. Please take me back to the history of your experience working with jaguars and/or wildlife trafficking and describe what you currently do.

\section{Jaguar Population Status and Threats:}

5. What are the main threats that jaguars are facing in the geographical areas that you work in? What do you base your answer on?

6. How would you rank those threats, from most important to least important? Please explain why.

\section{Supply:}

\section{Jaguar killing:}

7. In the areas about which you are able to provide information, do you know of any examples of jaguar killings? How long ago did those take place? How certain or uncertain are you about those events? Do you recall any other events?

8. In what locations did the jaguar killings take place and why?

\section{Motivations for killing jaguars}

9. In the areas about which you are able to provide information, what are currently the most common reasons behind jaguar killing? What do you base your answer on?

10. What do people who kill jaguars do with the carcasses in these areas?

People who kill jaguars

11. How would you describe the people who kill jaguars in present times these areas in terms of their nationality, ethnicity, age, gender, education level and occupation? Please describe the rationale for your description.

\section{Methods to kill jaguars}

12. What can you say about the methods used to kill jaguars in present times in these areas? Do you have any examples?

\section{Rewards and costs for killing jaguars}

13. Is there currently a legal or economic penalty for killing jaguars in these areas?

14. Are people in these areas aware of the penalty? What do you base your answer on?

15. Can you recall any examples of past penalties, prosecutions or law enforcement operations focused on jaguars in the areas you are able to tell me about? When did those happen?

\section{Situational factors leading to jaguar killings}

16. Are there any political or economic factors that may incentivize jaguar killings in present times in these areas? What do you base your answer on?

17. Is there any advantage to killing jaguars compared to other species? Why do you think that?

\section{Distribution}

\section{Middlemen}


18. How would you describe the jaguar trade middlemen in present times in terms of their nationality, ethnicity, age, gender, education level, occupation? Please describe the rationale for your description.

\section{Recruitment and communication}

19. How do jaguar traders find each other or recruit others? How certain or uncertain are you about your answer?

20. How do jaguar traders communicate with each other, and with suppliers and consumers?

\section{Smuggling}

21. How are the smuggled items concealed in present times? What do you base your answer on?

22. What are common packaging mechanisms?

23. What means of transportation and transport routes are used? How certain or uncertain are you of your answer?

\section{Organized crime}

24. Is there any evidence connecting jaguar traders with other kinds of criminal activity in present times in these areas? How certain or uncertain are you about your answer?

25. What do you think is the level of organization of jaguar trade? Why do you think that?

\section{Detection}

26. What kind of enforcement or detection strategy is currently in place in the areas about which you are able to provide information? What do you base your answer on?

\section{Market}

\section{Countries}

27. What regions or countries are the main markets of jaguar trade products in present times and why? What makes you think that?

28. Are you aware of any differences among the domestic and international markets of jaguar parts in terms of their scale, product types and uses, prices, etc.? How certain or uncertain are you about your answer?

\section{Physical and online markets}

29. Are you aware of any physical markets where jaguar body parts are being sold in present times in your areas?

30. In addition to physical markets, is there any evidence of online jaguar trade?

31. If so, what platforms are being used? Do you have any examples?

\section{Prices}

32. What are the current prices associated with jaguar body parts?

33. Are there any trends in the prices through the years? What makes you think that?

\section{Demand}

\section{Consumers}

34. How would you describe jaguar consumers in terms of their nationality, ethnicity, age, gender, education level, occupation? Please describe the rationale for your description.

\section{Drivers}

35. What are the drivers or motivations that each of those consumer groups might have for buying or using jaguar products? Why do you think that is? 
681

682

683

684

685

686

687

688

689

690

691

692

693

694

36. How are the products used? Can you give any examples?

\section{Countries}

If China (or other countries) was mentioned earlier:

37. Please describe how the international trade of jaguar body parts began in your area. What makes you think that?

38. What do you think that Chinese consumers (or other nationalities) use jaguar body parts for? What do you base your answer on?

\section{Strengths and Weaknesses}

39. What are some of the challenges to addressing jaguar trade in your area?

40. What are some of the strengths and weaknesses of your organization in particular when it comes to dealing with those challenges? 